\title{
Can the anti-inflammatory activities of $\beta 2$-agonists be harnessed in the clinical setting?
}

This article was published in the following Dove Press journal:

Drug Design, Development and Therapy

21 November 2013

Number of times this article has been viewed

\section{Annette J Theron ${ }^{1,2}$ \\ Helen C Steel' \\ Gregory R Tintinger' \\ Charles Feldman ${ }^{3}$ \\ Ronald Anderson'}

'Medical Research Council Unit for Inflammation and Immunity, Department of Immunology, Faculty of Health Sciences, University of Pretoria, ${ }^{2}$ Tshwane Academic Division of the National Health Laboratory Service, Pretoria, ${ }^{3}$ Division of Pulmonology, Department of Internal Medicine, Faculty of Health Sciences, University of the Witwatersrand and Charlotte Maxeke Johannesburg Academic Hospital, Johannesburg, South Africa
Correspondence: Annette J Theron Department of Immunology, Faculty of Health Sciences, University of Pretoria,

PO Box 2034, Pretoria 000I, South Africa

Tel +27 I2 319 2623

Fax +27 123230732

Email atheron@up.ac.za

\begin{abstract}
Beta2-adrenoreceptor agonists ( $\beta 2$-agonists) are primarily bronchodilators, targeting airway smooth muscle and providing critical symptomatic relief in conditions such as bronchial asthma and chronic obstructive pulmonary disease. These agents also possess broad-spectrum, secondary, anti-inflammatory properties. These are mediated largely, though not exclusively, via interactions with adenylyl cyclase-coupled $\beta 2$-adrenoreceptors on a range of immune and inflammatory cells involved in the immunopathogenesis of acute and chronic inflammatory disorders of the airways. The clinical relevance of the anti-inflammatory actions of $\beta 2$-agonists, although often effective in the experimental setting, remains contentious. The primary objectives of the current review are: firstly, to assess the mechanisms, both molecular and cell-associated, that may limit the anti-inflammatory efficacy of $\beta 2$-agonists; secondly, to evaluate pharmacological strategies, several of which are recent and innovative, that may overcome these limitations. These are preceded by a consideration of the various types of $\beta 2$-agonists, their clinical applications, and spectrum of anti-inflammatory activities, particularly those involving adenosine $3^{\prime}, 5^{\prime}$-cyclic adenosine monophosphate-activated protein kinase-mediated clearance of cytosolic calcium, and altered gene expression in immune and inflammatory cells.
\end{abstract}

Keywords: adenylyl cyclase, corticosteroids, cyclic AMP, muscarinic receptor antagonists, neutrophils, phosphodiesterase inhibitors

\section{Introduction}

Beta2-adrenergic agonists ( $\beta 2$-agonists) are widely used in clinical practice to treat patients with obstructive airway disorders, such as asthma, chronic obstructive pulmonary disease (COPD) and bronchiolitis obliterans. These agents relax airway smooth muscle, resulting in bronchodilatation, via interaction with G-protein-coupled $\beta 2$-adrenoreceptors ( $\beta 2 \mathrm{ARs}$ ), linked to adenylate cyclase. The consequence is elevation of intracellular cyclic adenosine monophosphate (cAMP) concentrations and activation of protein kinase A (PKA). ${ }^{1}$ In addition to their primary bronchodilatory effects, $\beta 2$-agonists have been shown to attenuate the proinflammatory activities of a range of immune and inflammatory cells in vitro, such as neutrophils, monocytes, mast cells, eosinophils, basophils, and lymphocytes, all of which contribute to the pathogenesis of various acute and chronic respiratory diseases. ${ }^{2}$ In addition, these agents have demonstrated efficacy in animal models of experimental acute lung injury. ${ }^{3,4}$ Clearly, the combination of bronchodilatory and anti-inflammatory activities is of considerable potential value in the pharmacotherapy of acute and chronic diseases of the airways, of both infective and noninfective origin. Disappointingly, however, $\beta 2$-agonists do not appear to possess significant anti-inflammatory activity in the clinical setting. 
The current review is focused on the cellular targets and mechanisms of anti-inflammatory activity of $\beta 2$-agonists, as well as on strategies, both current and future, that might enable these to be actualized in the clinical setting. This is preceded by a brief consideration of the current clinical applications and types of $\beta 2$-agonists.

\section{Types of $\boldsymbol{\beta} 2$-agonists}

These agents are characterized according to their duration of action, the three categories being: short-acting beta-agonist (SABA), long-acting beta agonist (LABA) and ultra-LABA. Some commonly used examples of these are shown in Table $1,{ }^{5,6-11}$ together with their types of agonist activity, partition coefficients, and durations of action. The number of $\beta 2$ ARs per cell on various immune and inflammatory cells, together with their dissociation constants, is summarized in Table 2. ${ }^{12-19}$ In the case of LABAs, formoterol has a more rapid onset of action than salmeterol, ${ }^{5}$ while both agents provide sustained bronchodilatation for at least 12 hours. ${ }^{20}$ Although indacaterol is the only example shown of an ultraLABA, several other such agents (abediterol, carmoterol, milveterol, olodaterol, vilanterol) are in the pipeline, ${ }^{5}$ while another, vilanterol, has recently received US Food and Drug Administration approval for therapy of COPD.

\section{$\beta 2$-adrenoceptor agonists and therapy of respiratory airway disorders}

SABAs are commonly used as rescue bronchodilator therapy to provide symptomatic relief for patients with exacerbations of asthma or COPD. Longer-term control of airway inflammation in asthma is usually achieved using inhaled corticosteroids (ICS). Significantly, LABAs in combination with ICS, currently play an important role in the management

Table I Types of commonly used $\beta_{2}$-agonists: their activity, partition coefficients, and duration of action

\begin{tabular}{|c|c|c|c|}
\hline Types & $\begin{array}{l}\text { Agonist } \\
\text { activity }\end{array}$ & $\begin{array}{l}\text { Partition } \\
\text { coefficient } \\
(\log P)\end{array}$ & $\begin{array}{l}\text { Duration } \\
\text { of action } \\
\text { (hours) }\end{array}$ \\
\hline \multicolumn{4}{|l|}{ Short acting } \\
\hline Salbutamol ${ }^{5-7,11}$ & Partial & $0.34-0.6$ & $4-6$ \\
\hline Terbutaline $^{7,11}$ & Partial & $0.44-0.55$ & $4-8$ \\
\hline Fenoterol $\left.\right|^{5,7,8,11}$ & Full & $1.36-1.47$ & $6-8$ \\
\hline \multicolumn{4}{|l|}{ Long acting } \\
\hline Salmeterol| ${ }^{5-7,11}$ & Partial & $3.6 \mathrm{I}-3.82$ & 12 \\
\hline Formoterol $^{5-7,11}$ & Full & $1.06-1.91$ & 12 \\
\hline \multicolumn{4}{|l|}{ Ultra-long acting } \\
\hline Indacaterol $\left.\right|^{5,7,9-11}$ & Full & $3.26-3.31$ & 24 \\
\hline
\end{tabular}

Table 2 The number of receptors per cell and dissociation constants of $\beta_{2}$-agonists in various immune and inflammatory cells

\begin{tabular}{lll}
\hline Cell type & $\begin{array}{l}\text { Number of receptors/ } \\
\text { cell }\left(\mathbf{B}_{\max }\right)\end{array}$ & $\begin{array}{l}\text { Dissociation } \\
\text { constant }\left(\mathbf{K}_{\mathrm{d}}\right)(\mathbf{p M})\end{array}$ \\
\hline Neutrophils $^{12}$ & $20878 \pm 2470$ (females) & \\
& $7331 \pm 3179$ (males) & \\
Macrophages $^{13}$ & $5643 \pm 942$ & $29 \pm 9$ \\
Monocytes $^{14}$ & $1000-3000$ & $38 \pm 29$ \\
Mast cells $^{15}$ & Variable btw preparations & $40 \pm 10$ \\
Epithelial cells $^{16}$ & $9908 \pm 1127$ (Calu-3 cells) \\
& $6423 \pm 895$ (I6HBEI4o(-) cells) \\
Eosinophils $^{17}$ & $4333 \pm 318$ & $25.3 \pm 1.4$ \\
T-cells $^{18,19}$ & $776 \pm 183 *$ & $19.7 \pm 1.6$ \\
\hline
\end{tabular}

Note: The results are expressed as the mean \pm standard error of the mean or *standard deviation.

Abbreviation: btw, between.

of chronic persistent asthma. ${ }^{21}$ Both types of $\beta 2$-agonists, as well as the more recently introduced ultra-LABAs, are generally considered to have good safety profiles, and these, as well as the cost-effectiveness of bronchodilator therapies, have been covered extensively in a recent review. ${ }^{1}$

There has been some concern that LABAs may mask ongoing airway inflammation in asthma and, accordingly, these agents should not be used as monotherapy in this condition. ${ }^{22}$ Beta-agonists are not recommended as monotherapy in asthma, as these agents may increase airway hyper-responsiveness, and increase the risk of death in patients with chronic asthma. ${ }^{23,24}$ In contradistinction to asthma, long-term use of LABAs as monotherapy in patients with COPD appears to be safe and effective. ${ }^{25}$ Importantly, however, the combination of low-dose ICS with a LABA has been shown to be more effective than high doses of ICS. ${ }^{26}$ This is supported by the findings of a study which demonstrated that the control of airway inflammation, determined by means of bronchial biopsies, was not compromised when asthmatic patients on high doses of ICS were switched to a combination of low-dose ICS and LABA. ${ }^{27}$ This is consistent with the well-documented anti-inflammatory interactions of combinations of LABAs and ICS, as discussed later in this review. Current guidelines for asthma therapy incorporate ICS/LABA combinations for patients not controlled on low doses of ICS. ${ }^{21,22}$

The role of LABAs in the management of COPD has been confirmed in a number of large randomized controlled trials, demonstrating improved pulmonary function tests, reduced frequency of exacerbations, and apparent slowing of the rate of decline of forced respiratory volume in 1 second ${ }^{28}$ Patients with symptomatic COPD may be given long-acting anticholinergics or LABAs as first-line therapy. In addition, some studies have shown LABAs to attenuate airway inflammation in COPD, and to decrease systemic markers of inflammation. ${ }^{29}$ 
Large clinical trials have indicated that LABAs are safe in COPD patients, as mentioned above. ${ }^{30,31}$ However, in patients with COPD, the use of ICS may be associated with an increased risk of pneumonia, which should be considered when using ICS/LABA combinations in this setting. ${ }^{5}$

Bronchiolitis obliterans is a chronic fibrotic disorder of small airways and bronchioles which results in progressive and usually fixed airflow obstruction. Adjunctive therapy with a combination of a LABA and ICS has been shown to provide symptomatic relief and significant improvement in airflow obstruction, in patients with this condition. ${ }^{32,33}$

Acute lung injury (ALI) is a common and serious disorder, characterized by alveolar flooding, neutrophil accumulation in the lungs, and markedly impaired gaseous exchange. Beta2- agonists have been reported to enhance fluid clearance from alveoli, to attenuate both neutrophil recruitment and proinflammatory activity, and to decrease endothelial permeability in experimental ALI., ${ }^{3,34}$ Consequently, $\beta 2$-agonists were considered potentially useful in ALI, a contention which was supported by data from limited human trials. ${ }^{35}$ However, recent, larger, randomized controlled trials have not shown improved outcomes for patients with ALI, treated with aerosolized or intravenous albuterol/salbutamol. ${ }^{34,36,37}$ Although $\beta 2 \mathrm{AR}$-desensitization may contribute to the lack of efficacy of intravenous salbutamol in the clinical setting of ALI, it is unlikely to be the only mechanism; others include the partial agonist properties of this agent, rendering it less potent than full agonists, with respect to the anti-inflammatory mechanisms described below.

\section{Anti-inflammatory activities of $\beta 2$-agonists}

Of the various types of immune and inflammatory cells involved in the immunopathogenesis of bronchial asthma and COPD, all have been reported to express $\beta 2$ ARs. Seemingly, neutrophils have the highest level of expression, albeit at lower density than airway smooth muscle cells (Table 2). Beta2-agonists have been reported to suppress the proinflammatory activities of all of these cell types (monocytes/ macrophages, basophils, eosinophils, mast cells, neutrophils, T lymphocytes), as well as those of airway structural cells (epithelial cells, fibroblasts, smooth muscle cells) by several distinct mechanisms. These are broadly categorized as being either cAMP-dependent or cAMP-independent, with LABAs (especially formoterol) being most effective, while little is known about the anti-inflammatory potential of ultraLABAs. The effects of $\beta 2$-agonists on various immune and inflammatory cells and their mediators are summarized in Table 3. 2,38,39
Table 3 The effects of $\beta_{2}$-agonists on various immune and inflammatory cells

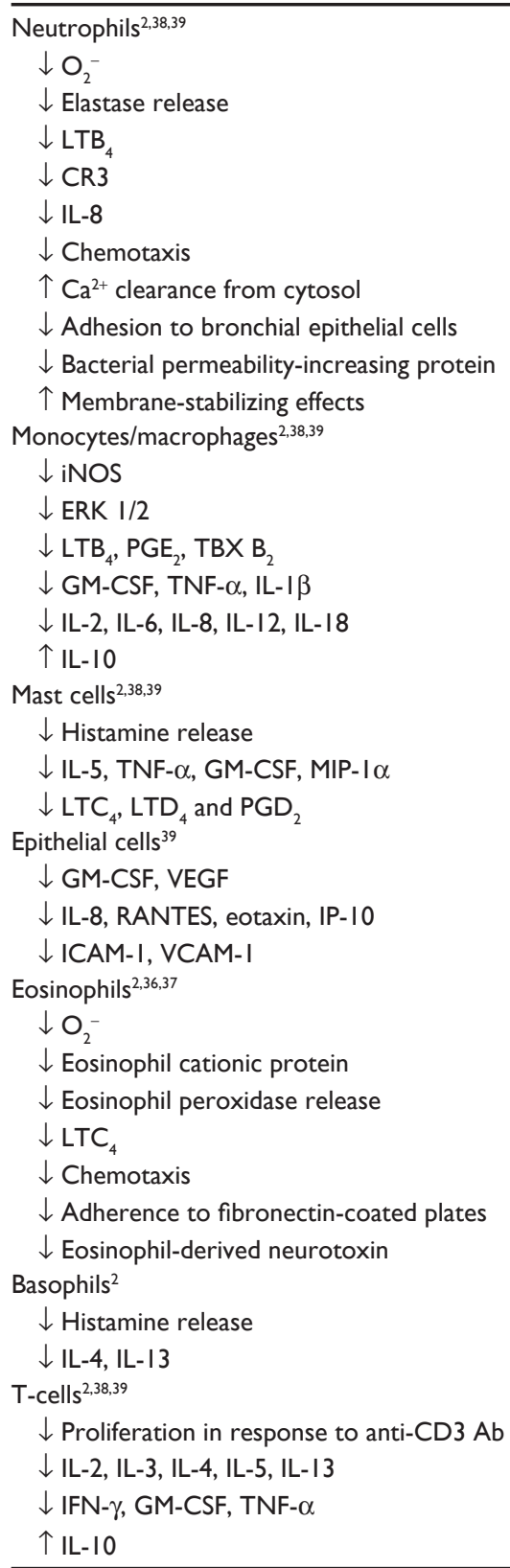

Abbreviations: $\mathrm{O}_{2}^{-}$, superoxide anion; iNOS, inducible nitric oxide synthase ERK, extracellular-regulated kinase; $\mathrm{LTB}_{4}$, leukotriene $\mathrm{B} 4 ; \mathrm{PGE}_{2}$, prostaglandin E2; TBX $B_{2}$, thromboxane B2; GM-CSF, granulocyte-macrophage colony-stimulating factor; TNF- $\alpha$, tumor necrosis factor alpha; IL-I $\beta$, interleukin-I beta; IL-; interleukin-; MIP-I $\alpha$, macrophage inflammatory protein I alpha; $L_{T}$, leukotriene D4; $P G D_{2}$, prostaglandin D2; VEGF, vascular endothelial growth factor; RANTES, regulated upon activation normal $T$ cell expressed and secreted; ICAM-I, intercellular adhesion molecule I; VCAM-I, vascular cell adhesion protein I; anti-CD3 Ab, antiCD3 monoclonal antibody; IFN- $\gamma$, interferon gamma; CR3, complement receptor 3; $\mathrm{LTC}_{4}$, leukotriene $\mathrm{C}_{4} ; \mathrm{IP}-10$, interferon $\gamma$ inducible protein.

\section{cAMP-dependent anti-inflammatory mechanisms}

Intracellular cAMP has two major targets, PKA and guanine nucleotide exchange protein directly activated by cAMP-1 (Epac1), both of which regulate the proinflammatory 
activities of various cell types, with the former mechanism being the best characterized. The major cellular targets of PKA are $\mathrm{Ca}^{2+}$ mobilization and clearance mechanisms, ${ }^{40-50}$ and regulation of the expression of genes encoding antiinflammatory/proinflammatory proteins at both the transcriptional and translational levels. ${ }^{51-74}$ Epac1 also appears to modulate gene expression. ${ }^{75-77}$

\section{Regulation of cytosolic $\mathrm{Ca}^{2+}$ fluxes by cAMP/PKA}

Several distinct, albeit interactive, mechanisms have been described, by which cAMP/PKA downregulates the $\mathrm{Ca}^{2+}$ dependent proinflammatory activities of immune and inflammatory cells, as well as structural cells. These mechanisms, which are best characterized in activated human neutrophils, are regulated by various types of cAMP-elevating agents, including 32 -agonists, agonists of subtype A2A adenosine receptors, and inhibitors of cAMP phosphodiesterases (PDEs), especially PDE4. ${ }^{40-43}$

In the case of neutrophils, receptor-mediated stimulation of these cells is accompanied by activation of phospholipase $\mathrm{C} \beta 3$ (PLC), which, in turn, cleaves membrane phosphatidylinositol to generate inositol triphosphate (IP3). This second messenger interacts with $\mathrm{Ca}^{2+}$-mobilizing IP3 receptors on intracellular $\mathrm{Ca}^{2+}$ stores (calciosomes, endoplasmic reticulum), resulting in an abrupt, transient increase in cytosolic $\mathrm{Ca}^{2+}$. This is a critical event, which precedes, and is a prerequisite for, activation of most of the proinflammatory activities of these cells, including: i) generation of both reactive oxygen species and the eicosanoid, leukotriene B4 ( $\left.\mathrm{LTB}_{4}\right)$; ii) mobilization of cytosolic granules; and iii) $\beta 2$-integrin-mediated firm adhesion to vascular endothelium. ${ }^{42}$

To counter neutrophil hyper-reactivity, these events are stringently regulated by several cAMP/PKA-dependent mechanisms, which interact to restore $\mathrm{Ca}^{2+}$ homeostasis. These are: i) phosphorylative inactivation of PLC by PKA; ${ }^{44}$ ii) upregulation of the activity of the $\mathrm{Ca}^{2+}$-resequestering endomembrane $\mathrm{Ca}^{2+}$ ATPase (adenosine triphosphatase; probably via phosphorylation of serine (Ser)16 on the phospholamban regulatory subunit); ${ }^{41}$ iii) inactivation of the IP3 receptor; ${ }^{45}$ iv) inhibition of influx of extracellular $\mathrm{Ca}^{2+}$, via regulation of storeoperated $\mathrm{Ca}^{2+}$ channels; ${ }^{46}$ and v) phosphorylative inactivation of p38 mitogen-activated protein kinase (MAPK), resulting in failure of activation of $5^{\prime}$-lipoxygenase (5-LO), with resultant attenuation of an autocrine, $\mathrm{LTB}_{4}$-mediated secondary wave of $\mathrm{Ca}^{2+}$ influx; ${ }^{47}$ in addition, PKA-mediated phosphorylation of 5-LO inhibits the nuclear import of this enzyme. ${ }^{48}$
In this setting of restoration of $\mathrm{Ca}^{2+}$ homeostasis to activated neutrophils, the autocrine interaction of adenosine with G-protein/adenylyl cyclase-coupled A2A receptors appears to be the primary mechanism for generation of cAMP, ${ }^{49,50}$ which is complemented by $\beta 2$-agonists and PDE4 inhibitors. ${ }^{43}$

\section{PKA modulation of inflammatory/ anti-inflammatory gene expression}

Cyclic AMP/PKA-dependent, gene-targeted, antiinflammatory mechanisms are also operative at several levels, including: i) antagonism of transcription factors; ${ }^{51,52}$ ii) induction of synthesis of the anti-inflammatory cytokine, interleukin (IL)-10,3,53-57 and iii) potentiation of glucocorticoid (GC)/glucocorticoid receptor (GR)-activated gene transcription, which contributes to the beneficial therapeutic interactions of LABAs with ICS. ${ }^{58-74}$

\section{Antagonism of transcription factors by PKA}

Activation of PKA results in phosphorylation of the transcription factor, cAMP response binding protein (CREB), which, in turn, competes with proinflammatory transcription factors, such as nuclear factor kappa B (NF- $\mathrm{B}$ ), and activator protein-1, for limited binding sites on the transcriptional coactivator, with intrinsic histone acetyl transferase activity and CREB-binding protein. This mechanism, which has been described in epithelial cells and macrophages, results in decreased expression of genes encoding a range of proinflammatory proteins. ${ }^{51,52}$

\section{Modulation of IL- I 0 gene expression by PKA}

The promoter region of the IL-10 gene contains a cAMP response element. Gene transcription results, in turn, from PKA-mediated phosphorylation of CREB, a known transcription factor for IL-10 promoter activation. This antiinflammatory mechanism is operative in several cell types, such as dendritic cells and macrophages, ${ }^{3,53-56}$ and may be particularly important in controlling neutrophilic inflammation, as these cells respond to, but do not produce, IL-10. ${ }^{57}$

\section{Potentiation of glucocorticoid receptor-activated gene transcription by $\mathrm{CAMP} / \mathrm{PKA}$}

Cyclic AMP/PKA-activating agents, particularly LABAs, have well documented enhancing actions, both direct and indirect, on the GR/glucocorticoid response element 
(GRE) dependent transactivation of genes encoding antiinflammatory proteins. ${ }^{58}$ These effects are complex, and are achieved primarily via positive, site-specific phosphorylation of serine residues situated in the regulatory N-terminal region of the GR, either by PKA directly, or indirectly, via PKA-mediated phosphorylation of other kinases, such as cyclin-dependent kinases..$^{59,60}$ These events have been described in a variety of cell types, including airway epithelial cells, smooth muscle cells, fibroblasts, and monocytes/macrophages, as well as hippocampal progenitor cells. They result in the following: i) increased stability and nuclear translocation of the GR, both ligand-dependent and ligand-independent; and ii) increased transcriptional efficiency, via enhanced GRE binding of the activated GR, apparently via recruitment of transcription-promoting coregulatory proteins. ${ }^{58-69}$ The consequence is activation of genes encoding a series of anti-inflammatory proteins. One of these, MAPK phosphatase-1, also promotes stabilization of the GR via dephosphorylative inactivation of p38 MAPK and c-jun-N-terminal kinase (JNK), both of which phosphorylate the GR at position Ser226, inhibiting translocation and GRE binding. ${ }^{69}$ Inactivation of these kinases by MAPK phosphatase- 1 also attenuates their ability to activate several proinflammatory transcription factors.

These GR-targeted activities of LABAs are complemented by several other cAMP/PKA-dependent mechanisms, including: i) increased expression of functional GRs by stabilization of GR messenger (m)RNA; ${ }^{58}$ ii) phosphorylative inhibition of phosphatidylinositol-3 kinase (PI3 K)/ protein kinase B (Akt) signaling, which prevents inactivation of histone deacetylase 2, increasing the efficiency of GRmediated repression of genes encoding proinflammatory proteins; $;^{70,71}$ and iii) interference with $\mathrm{LTB}_{4}$ production, thereby antagonizing the antiapoptotic/proinflammatory effects of GR activation on neutrophils and monocytes, which are mediated via upregulation of expression of the $\mathrm{LTB}_{4}$ receptor 1 , BTL1. ${ }^{72}$

As well as underpinning the improved efficacy of ICS in patients receiving combination therapy with LABAs, these various cAMP/PKA-mediated mechanisms may also attenuate the development of corticosteroid (CS) resistance. ${ }^{26,58,69,71,73,74}$

\section{Epacl}

Cyclic AMP has also been reported to suppress the proinflammatory activities of several cell types, including macrophages, microglia, and epithelial cells, by a PKA-independent mechanism. In this setting, the alternative target of cAMP is Epac1, the substrate of which is the Ras-like, small guanosine triphosphatase, Rap $1 .{ }^{75}$ Notwithstanding effects on the cytoskeleton, ${ }^{76}$ Epac1, acting via Rap1, modulates the proinflammatory activities of NF- $\kappa \mathrm{B}$ and glycogen synthase kinase $-3 \beta$, resulting in decreased synthesis of tumor necrosis factor by target cells. ${ }^{77}$

These various mechanisms of cAMP-mediated antiinflammatory activity are summarized in Table 4.

\section{Cyclic AMP/PKA-independent mechanisms of $\beta 2$-agonist-mediated anti-inflammatory activity}

Although the anti-inflammatory mechanisms of $\beta 2$-agonists are mediated predominantly by cAMP/PKA-dependent mechanisms, the existence of alternative mechanisms has been described in various cell types, including bronchial epithelial cells and macrophages. ${ }^{3,78-80}$ Perhaps the most significant of these was described in a recent study, in which formoterol was found to cause $\beta 2 \mathrm{AR}$-independent activation of the serine/threonine phosphatase, PP2A. ${ }^{80}$ Activation of PP2A, in turn, reversed JNK-mediated phosphorylation of the GR at Ser226, thereby increasing CS sensitivity.

Table 4 cAMP-mediated mechanisms of anti-inflammatory activity

\begin{tabular}{|c|c|}
\hline Target & Effect \\
\hline \multicolumn{2}{|l|}{ Protein kinase A-mediated } \\
\hline $\begin{array}{l}\text { Regulation of } \mathrm{Ca}^{2+} \text { mobilization } \\
\text { and cytosolic clearance } \\
\text { in activated immune } \\
\text { and inflammatory cells }\end{array}$ & $\begin{array}{l}\text { Downregulation of } \mathrm{Ca}^{2+} \text {-dependent } \\
\text { proinflammatory activities }{ }^{40-48}\end{array}$ \\
\hline $\begin{array}{l}\text { - Antagonism of proinflammatory } \\
\text { transcription factors } \\
\text { (NFKB, AP-I, others) }\end{array}$ & $\begin{array}{l}\text { Decreased expression of genes } \\
\text { encoding proinflammatory } \\
\text { proteins }^{51,52}\end{array}$ \\
\hline $\begin{array}{l}\text { Interaction of CREB with the } \\
\text { promoter region of the IL-10 } \\
\text { gene }\end{array}$ & Activation of synthesis of IL- $10^{53-56}$ \\
\hline $\begin{array}{l}\text { Potentiation of GR/GRE- } \\
\text { mediated gene transcription } \\
\text { (trans-activation) }\end{array}$ & $\begin{array}{l}\text { Activation of synthesis of other } \\
\text { anti-inflammatory proteins }{ }^{58-69}\end{array}$ \\
\hline - Inhibition of $5^{\prime}$-lipoxygenase & $\begin{array}{l}\text { Decreased production of } \\
\text { proinflammatory leukotrienes, } \\
\text { and antagonism of glucocorticoid- } \\
\text { mediated anti-apoptotic effects on } \\
\text { neutrophils }{ }^{47,48,72}\end{array}$ \\
\hline \multicolumn{2}{|l|}{ Epacl-mediated } \\
\hline $\begin{array}{l}\text { - Antagonism of NFKB and } \\
\text { glycogen synthase kinase }\end{array}$ & Decreased production of $\mathrm{TNF}^{75,77}$ \\
\hline
\end{tabular}

Abbreviations: cAMP, cyclic adenosine monophosphate; NFKB, nuclear factor kappa B; AP-I, activator protein-I; CREB, CAMP response element-binding protein; IL-10, interleukin 10; GR, glucocorticoid receptor; GRE, glucocorticoid response element; TNF, tumor necrosis factor; Epacl, guanine nucleotide exchange protein directly activated by cAMP-I. 


\section{Mechanisms which restrict the anti- inflammatory efficacy of $\beta 2$-agonists}

Beta2-agonists, especially LABAs, are ineffective, possibly harmful, when used as monotherapy in bronchial asthma, administered intravenously, or used in aerosols in patients with ALI. ${ }^{36,37,81}$ This seems surprising, given the broad range of cellular targets and inflammatory mediators which are negatively regulated by cAMP.

Notwithstanding differences in molecular structure, agonist activity, and duration of action, the following mechanisms, operative in airway smooth cells, are also likely to undermine the anti-inflammatory efficacy of $\beta 2$-agonists: i) homologous receptor desensitization; ${ }^{26,73,81,82}$ and ii) induction of cAMP-specific PDE4. ${ }^{82,73,83}$ These mechanisms are compounded by the lower numbers of $\beta 2 \mathrm{ARs}$ on immune and inflammatory cells, relative to those present on airway smooth muscle. ${ }^{38}$

\section{Receptor desensitization}

Homologous receptor desensitization and downregulation of receptor expression, following extended use of $\beta 2$-agonists, are considered to be major limitations of these agents, with respect to anti-inflammatory activity.,26,73,81 In this setting, prolonged activation of the $\beta 2 \mathrm{AR}$ results in sequential uncoupling of the receptor from adenylyl cyclase, internalization and phosphorylation by $\beta A R$ kinases, PKA and G-protein-coupled receptor kinases, with resultant desensitization. ${ }^{73}$ Extended exposure to $\beta 2$-agonists also results in decreased $\beta 2 \mathrm{AR}$ gene transcription and receptor expression. ${ }^{73}$ These mechanisms, compounded by the relatively low numbers of $\beta 2 A R s$ on immune and inflammatory cells,${ }^{38}$ are likely to restrict not only the anti-inflammatory potential of $\beta 2$-agonists, but also that of endogenous catecholamines.

In addition, prolonged exposure to $\beta 2$-agonists has also been reported to cause heterologous receptor desensitization (cross-desensitization) in airway smooth muscle cells, via the aforementioned mechanisms. ${ }^{82,84}$ Although it is speculative, heterologous receptor desensitization, if operative in vivo, may attenuate other types of endogenous, receptor-mediated, cAMP-dependent, anti-inflammatory mechanisms, such as those involving activation of adenosine $\mathrm{A} 2 \mathrm{~A}$ receptors. ${ }^{85}$

\section{Induction of cAMP-specific PDE4}

Prolonged exposure of airway smooth muscle cells has also been reported to result in increased transcription of the gene encoding PDE4D5, the predominant isoform present in these cells, by mechanisms involving PKA and extracellular-regulated kinase $1 / 2 .{ }^{82,84,86}$ The consequence is markedly decreased levels of intracellular cAMP and loss of responsiveness to $\beta 2$-agonists, which can be prevented by pretreatment of the cells with selective and nonselective inhibitors of PDE4. ${ }^{82,84,86}$

\section{$\beta 2$-adrenoreceptors on immune and inflammatory cells}

Because they express lower numbers of $\beta 2$ ARs, immune and inflammatory cells are likely to be particularly prone to loss of sensitivity to $\beta 2$-agonists by the aforementioned mechanisms. The probable consequence is attenuation of the cAMP-dependent anti-inflammatory mechanisms described above.

\section{Pharmacological strategies which potentiate the anti-inflammatory activities of $\boldsymbol{\beta} \mathbf{2}$-agonists}

Several pharmacological strategies, some well-established and others currently in the preclinical and clinical phases of evaluation, have been described that may counter $\beta 2 \mathrm{AR}$ desensitization and increased activity of PDEs.

\section{Combining LABAs with CS}

As described above, combining LABAs with CS into a single inhaler device has proven to be a major innovation in the therapy of bronchial asthma. ${ }^{26,73}$ The magnitude of improvement in asthma control resulting from a LABA/ICS combination is superior to that achieved with high doses of ICS alone. ${ }^{87}$ Similarly, for patients with COPD, the clinical efficacy of a LABA/ICS combination is significantly greater than with either agent used as monotherapy. ${ }^{88}$ Commonly used LABA/ICS combinations, together with their times of onset of action, efficacies, and adverse effects are shown in Table 5 .

It is generally assumed that the primary role of the LABA is to augment the anti-inflammatory actions of the $\mathrm{CS}$, by the mechanisms described in the preceding sections. ${ }^{83}$ However, CS can also augment the anti-inflammatory actions of LABAs, consistent with synergistic interactions between the two components. These mechanisms include CS-mediated increases in: i) the numbers of $\beta 2 A R s$, by potentiating receptor gene transcription; and ii) the efficacy of coupling between the $\beta 2 \mathrm{AR}$ and its Gs-protein subunit. The consequence is enhanced and sustained cellular responses to $\beta 2$-agonists. ${ }^{73}$ 
Table 5 Inhaled bronchodilator therapies that may be used alone or in combination for the management of chronic stable COPD

\begin{tabular}{|c|c|c|c|}
\hline Class of agent & Onset of action & Therapeutic efficacy & Adverse effects \\
\hline \multicolumn{4}{|l|}{ LABA* } \\
\hline Formoterol ${ }^{98-111}$ & 10 minutes & $\uparrow$ Lung functions & Tremor \\
\hline \multirow[t]{3}{*}{ Salmeterol97,112 } & 3 hours & $\uparrow$ Quality of life & Headache \\
\hline & & $\downarrow$ Symptoms & Cough \\
\hline & & & Cardiac toxicity \\
\hline \multicolumn{4}{|l|}{ LABA + ICS* } \\
\hline Formoterol/budesonide $98,100,103,113$ & As above for & $\uparrow$ Lung functions & Tremor \\
\hline \multirow[t]{4}{*}{ Salmeterol/fluticasone $\mathrm{e}^{97,104,106,108,109,114}$} & LABAs & $\uparrow$ Quality of life & Headache \\
\hline & & $\downarrow$ Symptoms & Cough \\
\hline & & $\downarrow$ Exacerbations & Cardiac toxicity \\
\hline & & & Pneumonia \\
\hline \multicolumn{4}{|l|}{ LAMA } \\
\hline \multirow[t]{4}{*}{ Tiotropium $97,107,|| 10,|| 12,|13| 115-120}$, & $3-4$ hours & $\uparrow$ Lung functions & Dry mouth \\
\hline & & $\uparrow$ Quality of life & Hoarseness \\
\hline & & $\downarrow$ Symptoms & Cardiac toxicity \\
\hline & & $\downarrow$ Exacerbations & Pneumonia \\
\hline \multicolumn{4}{|l|}{ LABA + LAMA } \\
\hline Formoterol + tiotropium 21 |-124,125 & As above & As above & As above \\
\hline Salmeterol + tiotropium 126,127 & As above & As above & As above \\
\hline LABA + LAMA + ICS 226,128 & As above & As above & As above \\
\hline \multicolumn{4}{|l|}{ Ultra-LABA } \\
\hline \multirow[t]{4}{*}{ Indacatero| ${ }^{99,129,130}$} & 5 minutes & $\uparrow$ Lung functions & Cough \\
\hline & & $\uparrow$ Quality of life & Nasopharyngitis \\
\hline & & $\downarrow$ Symptoms & Worsening \\
\hline & & $\downarrow$ Exacerbations & COPD \\
\hline \multicolumn{4}{|l|}{ Experimental agents } \\
\hline Various Ultra-LABAs ${ }^{129}$ & To be established & See Ultra-LABA & See Ultra-LABA \\
\hline New LAMAs $s^{127}$ & & See LAMA & See LAMA \\
\hline Glycopyrronium & To be established & & \\
\hline \multicolumn{4}{|l|}{ GSK-5737I9 } \\
\hline \multicolumn{4}{|l|}{ BEA-2I80BR } \\
\hline \multicolumn{4}{|l|}{ Aclidinium bromide } \\
\hline Darotropium bromide & & & \\
\hline
\end{tabular}

Notes: *Randomized placebo-controlled trials of duration $>24$ weeks have been selected, as this duration allows the best assessment of treatment effects. Data from Decramer et al."'I

Abbreviations: COPD, chronic obstructive pulmonary disease; LABA, long-acting beta agonist; ICS, inhaled corticosteroid; LAMA, long-acting muscarinic agent.

\section{Combining LABAs with inhibitors of PDE4}

Clearly, pharmacological strategies that target PDEs (the enzymes that inhibit the hydrolysis of cyclic nucleotides) are attractive for potentiating the anti-inflammatory actions of cAMP-elevating agents, including $\beta 2$-agonists. One such agent, roflumilast, is a selective inhibitor of type $4 \mathrm{PDE}$, the predominant type in human neutrophils, and which is also present in other types of immune and inflammatory cells. This agent has been approved for clinical application in COPD, while several other such agents are in the pipeline. ${ }^{83,89,90}$ Interestingly, roflumilast has been reported to enhance the potentiating action of formoterol on CS-mediated gene transcription in human airway epithelial cells in vitro. ${ }^{91}$ However, drug intolerance due to gastrointestinal and central nervous system side-effects may be limiting, while therapeutic efficacy has also been questioned by some. ${ }^{92}$ To counter these problems, inhaled formulations of roflumilast, for use in combination with ICS/LABAs, are currently under development, as are other novel PDE4 inhibitors, for both oral and inhaled administration, with apparently improved windows of therapeutic efficacy. ${ }^{89}$ Moreover, given that PDE4 is not the only isoform present in immune and inflammatory cells (with one or both of PDE3 and PDE7 also being present, both of which hydrolyze cAMP), there is an increasing realization that simultaneous targeting of several PDE isoforms may be a more effective strategy. ${ }^{90}$

In this respect, it is noteworthy that montelukast, an antagonist of type 1 cysteinyl leukotriene receptors (CysLT1Rs), which is used primarily in the therapy of exercise-induced asthma (and as add-on therapy to ICS/ LABAs in severe asthma, as well as in some cases of 
moderate-to-severe COPD), has also been reported to possess secondary, nonspecific PDE-inhibitory activity. ${ }^{93}$ Exposure of human neutrophils to montelukast alone, but especially in combination with formoterol, was found to suppress the proinflammatory activities of these cells by a CysLT1Rindependent, apparently cAMP-mediated, mechanism. ${ }^{43,93,94}$ Interestingly, montelukast has recently been reported to prevent salbutamol-mediated $\beta 2 \mathrm{AR}$ desensitization in airway smooth muscle cells, via direct inhibition of PDE4D5. ${ }^{86}$

Other agents which possess this combination of CysLT1R-antagonism and nonspecific PDE inhibitory activity include ibudilast (also known as KC-404, AV-411 and MN-166) and CR3465. Ibudilast is currently undergoing clinical evaluation as a treatment for chronic neuropathic pain and multiple sclerosis, while CR3465 is under early assessment as a potential therapy for bronchial asthma and interstitial cystitis. ${ }^{93}$ Clearly, all three of these agents have the potential to augment the anti-inflammatory activities of LABAs in the clinical setting, with supporting evidence, albeit limited, in the case of montelukast. ${ }^{95,96}$

\section{Combinations of anticholinergics with $\beta 2$-agonists}

Anticholinergic agents induce bronchodilation by antagonism of muscarinic receptors on smooth muscle cells. The shortacting anti-muscarinic agent, ipratropium bromide provides short-term symptomatic relief for patients with airflow obstruction, while longer-acting muscarinic agents (LAMAs), such as tiotropium, maintain bronchodilatation for a sustained period. ${ }^{97}$ A number of new-generation LAMAs are currently being developed, as shown in Table 5. Because LAMAs and LABAs act via separate mechanisms, the combination of these two agents may induce greater bronchodilatation than either agent alone. Clinical trials support the safety and efficacy of LABA/ LAMA combinations for the management of COPD. ${ }^{97}$

Triple therapy with a LABA/LAMA/ICS combination has been used for patients with severe COPD who do not respond adequately to other therapeutic regimens. There does appear to be some additional benefit to be gained by following this strategy of triple therapy for selected patients. ${ }^{97}$

In addition to its bronchodilating actions, tiotropium also possesses anti-inflammatory activities, albeit by mechanisms that remain to be conclusively established. ${ }^{130}$ Given their potential complementary bronchodilatory and antiinflammatory actions, several recent studies have addressed the therapeutic potential of combinations of tiotropium with either LABAs or ultra-LABAs only, or with ICS/LABAs, in the clinical setting of COPD. Improvements in several clinical and inflammatory indices were observed. ${ }^{131-134}$ Likewise, combining tiotropium as add-on therapy to ICS/ LABAs in patients with severe, uncontrolled asthma was found to improve lung function over 24 hours. ${ }^{135}$ Although promising, firm recommendations on the clinical utility of combining tiotropium with either LABAs/ultra-LABAs, or as a single bifunctional molecule, ${ }^{136}$ with or without $\mathrm{CS}$, in the therapy of COPD or asthma cannot be made on the basis of the limited data currently available. ${ }^{131-132}$ This needs to be reinforced, not only by additional clinical trial data, but also by the acquisition of compelling mechanistic data on the possible additive/synergistic anti-inflammatory interactions of tiotropium with $\beta 2$-agonists and CS.

\section{Conclusion}

LABAs are used in the management of obstructive airways diseases, primarily for their very effective bronchodilator activity. ${ }^{1}$ They are an established therapy for COPD, often as single agents, and are considered to be safe and effective in this condition. ${ }^{9,11,12}$ However, since their introduction, controversy has surrounded the use of LABAs in asthma with concerns that their use as monotherapy is associated with adverse outcomes, including an increase in asthma exacerbations and mortality. ${ }^{137}$ Accordingly, they are always used in combination with a conventional anti-inflammatory agent, most commonly ICS. ${ }^{22,26}$ However, the improved control of asthma, together with reduced airway responsiveness to allergen challenge, achieved by combining LABAs with an ICS (as opposed to simply increasing the dose of the ICS) has been interpreted by some as evidence for anti-inflammatory activity of $\beta 2$-agonists. ${ }^{137} \mathrm{~A}$ better understanding of the mechanisms which both underpin and counteract the antiinflammatory potential of $\beta 2$-agonists may facilitate the design of pharmacological strategies to optimize the clinical benefit of these agents.

\section{Disclosure}

$\mathrm{CF}$ has acted on the Advisory Board and/or received honoraria for lectures and/or received assistance for congress travel from Aspen-GSK, Boehringer Ingelheim, Cipla Medpro, and Novartis. The other authors have no conflicts of interest to declare.

\section{References}

1. Cazzola M, Page CP, Rogliani P, Matera MG. $\beta 2$-agonist therapy in lung disease. Am J Respir Crit Care Med. 2013;187(7):690-696.

2. Johnson M. Effects of $\beta 2$-agonists on resident and infiltrating inflammatory cells. J Allergy Clin Immunol. 2002;110(Suppl 6): S282-S290.

3. Bosmann M, Grailer JJ, Zhu K, et al. Anti-inflammatory effects of $\beta 2$ adrenergic receptor agonists in experimental acute lung injury. FASEB J. 2012;26(4):2137-2144. 
4. Hoyle GW. Mitigation of chlorine lung injury by increasing cAMP levels. Proc Am Thorac Soc. 2012;7(4):284-289.

5. Fuso L, Mores N, Valente S, Malerba M, Montuschi P. Long-acting beta-agonists and their association with inhaled corticosteroids in COPD. Curr Med Chem. 2013;20(12):1477-1495.

6. Naline E, Trifilieff A, Fairhurst RA, Advenier C, Molimard M. Effect of indacaterol, a novel long-acting $\beta 2$-agonist, on isolated human bronchi. Eur Respir J. 2007;29(3):575-581.

7. Woo AY, Wang TB, Zeng X, et al. Stereochemistry of an agonist determines coupling preference of b2-adrenoceptor to different $\mathrm{G}$ proteins in cardiomyocytes. Mol Pharmacol. 2009;75(1):158-165.

8. Malerba M, Radaeli A, Morjaria JB. Therapeutic potential for novel ultra long-acting $\beta 2$-agonists in the management of COPD: biological and pharmacological aspects. Drug Discov Today. 2012;17(9-10):496-504.

9. Tamm M, Richards DH, Beghé B, Fabbri L. Inhaled corticosteroid and long-acting $\beta 2$-agonist pharmacological profiles: effective asthma therapy in practice. Respir Med. 2012;106 Suppl 1:S9-S19.

10. Yorgancioglu A. Indacaterol in chronic obstructive pulmonary disease: an update for clinicians. Ther Adv Chronic Dis. 2012;3(1):25-36.

11. DrugBank 3.0: a comprehensive resource for 'omics' research on drugs. Nucleic Acids Res. 2011;39(Database issue):D1035-D1041.

12. De Coupade C, Gear RW, Dazin PF, Sroussi HY, Green PG, Levine JD. Beta 2-Adrenergic receptor regulation of human neutrophil function is sexually dimorphic. Br J Pharmacol. 2004;143(8):1033-1041.

13. Liggett SB. Identification and characterization of a homologous population of beta 2-adrenergic receptors on human alveolar macrophages. Am Rev Respir Dis. 1989;139(2):552-555.

14. Lonati-Galligani M, Pirke KM. Beta 2-adrenergic receptor regulation in circulating mononuclear leukocytes in anorexia nervosa and bulimia Psychiatry Res. 1986;19(3):189-198.

15. Chong LK, Chess-Williams R, Peachell PT. Pharmacological characterisation of the $\beta$-adrenoceptor expressed by human lung mast cells. Eur J Pharmacol. 2002;437(1-2):1-7.

16. Abraham G, Kneuer C, Ehrhardt C, Honscha W, Ungemach FR. Expression of functional beta2-adrenergic receptors in the lung epithelial cell lines 16HBE14o(-), Calu-3 and A549. Biochim Biophys Acta. 2004;1691(2-3):169-179.

17. Yukawa T, Ukena D, Kroegel C, et al. Beta2-adrenergic receptors on eosinophils: binding and functional studies. Am J Resp Crit Care Med. 1990;141(6):1446-1452.

18. Landmann R. Beta-adrenergic receptors in human leukocyte subpopulations. Eur J Clin Invest. 1992;22 Suppl 1:30-36.

19. Anstead MI, Hunt TA, Carlson SL, Burki NK. Variability of peripheral blood lymphocyte beta-2-adrenergic receptor density in humans. Am J Crit Care Med. 1998;157(3 Pt 1):990-992.

20. Oppenheimer J, Nelson HS. Safety of long-acting $\beta$-agonists in asthma: a review. Curr Opin Pulm Med. 2008;14(1):64-69.

21. Rogers L, Reibman J. Stepping down asthma treatment: how and when. Curr Opin Pulm Med. 2012;18(1):70-75.

22. Antoniu SA. Effects of inhaled therapy on biomarkers of systemic inflammation in stable chronic obstructive pulmonary disease. Biomarkers. 2010;15(2):97-103.

23. Taylor DR. The beta-agonist saga and its clinical relevance: on and on it goes. Am J Respir Crit Care Med. 2009;179 (11):976-978.

24. Nelson HS, Weiss ST, Bleecker ER, Yancey SW, Dorinsky PM, SMART Study Group. The Salmeterol Multicenter Asthma Research Trial: a comparison of usual pharmacotherapy for asthma or usual pharmacotherapy plus salmeterol. Chest. 2006;129(1):15-26.

25. Calverley PM, Anderson JA, Celli B, et al. Salmeterol and fluticasone propionate and survival in chronic obstructive pulmonary disease. N Engl J Med. 2007;356(8):775-789.

26. Chung KF, Caramori G, Adcock IM. Inhaled corticosteroids as combination therapy with $\beta$-adrenergic agonists in airways disease: present and future. Eur J Clin Pharmacol. 2009;65(9):853-871.

27. Jarjour NN, Wilson SJ, Koenig SM, et al. Control of airway inflammation maintained at a lower steroid dose with 100/50 microg of fluticasone propionate/salmeterol. J Allergy Clin Immunol. 2006;118(1):44-52.
28. Welte T. Optimising treatment for COPD - new strategies for combination therapy. Int J Clin Prac. 2009;63(8):1136-1149.

29. King P. Role of arformoterol in the management of COPD. Int J COPD. 2008;3(3):385-391.

30. Sin DD, Man P, Marciniuk DD, et al. The effects of fluticasone with or without salmeterol on systemic biomarkers of inflammation in chronic obstructive pulmonary disease. Am J Respir Crit Care Med. 2008;177(11):1207-1214.

31. Hanania NA. The impact of inhaled corticosteroid and long acting $\beta$-agonist combination therapy on outcomes in COPD. Pulm Pharmacol Therap. 2008;21(3):540-550.

32. Pandya CM, Soubani AO. Bronchiolitis obliterans following hematopoietic stem cell transplantation: a clinical update. Clin Transplant. 2012; 24(3):291-306.

33. Hildebrandt GC, Fazekas T, Lawitschka A, et al. Diagnosis and treatment of pulmonary chronic GVHD: report from the consensus conference on clinical practice in chronic GVHD. Bone Marrow Transplant. 2011;46(10):1283-1295.

34. Papazian L. Con: $\beta 2$-Adrenergic agonists in ALI-ARDS - not recommended or potentially harmful? Am J Resp Crit Care Med. 2011;184(5): 504-506.

35. Roca O, Gómez-Ollés S, Cruz M-J, Huñuz X, Griffiths MJD, Mascians JR. Effects of salbutamol on exhaled breath condensate biomarkers in acute lung injury: prospective analysis. Crit Care. 2008;12(3):R72.

36. National Heart, Lung, and Blood Institute Acute Respiratory Distress Syndrome (ARDS) Clinical Trials Network. Randomized, placebocontrolled clinical trial of an aerosolized $\beta 2$-agonist for treatment of acute lung injury. Am J Respir Crit Care. 2011;184(5):561-568.

37. Gao Smith F, Perkins GD, Gates S, et al. Effect of intravenous $\beta-2$ agonist treatment on clinical outcomes in acute respiratory distress syndrome (BALTI-2): a multicentre, randomised controlled trial. Lancet. 2012;379(9812): 229-235.

38. Barnes PJ. Effect of $\beta$-agonists on inflammatory cells. J Allergy Clin Immunol. 1999;104(2 Pt 2):S10-S17.

39. Hanania NA, Moore RH. Anti-inflammatory activities of beta 2-agonists Curr Drug Targets Inflamm Allergy. 2004;3(3):271-277.

40. Anderson R, Goolam Mahomed A, Theron AJ, Ramafi G, Feldman C. Effect of rolipram and dibutyryl cyclic AMP on resequestration of cytosolic calcium in FMLP-activated human neutrophils. Br J Pharmacol. 1998;124(3):547-555.

41. Anderson R, Visser SS, Ramafi G, Theron AJ. Accelerated resequestration of cytosolic calcium and suppression of the pro-inflammatory activities of human neutrophils by CGS 21680 in vitro. Br J Pharmacol. 2000;130(4):717-724

42. Tintinger GR, Steel HC, Theron AJ, Anderson R. Pharmacological control of neutrophil-mediated inflammation: Strategies targeting calcium handling by activated polymorphonuclear leukocytes. Drug Des Dev Ther. 2009;2:95-104.

43. Gravett CM, Theron AJ, Steel HC, et al. Interactive inhibitory effects of formoterol and montelukast on activated human neutrophils. Eur Respir J. 2010;36(6):1417-1424.

44. Ali H, Sozzani S, Fisher I, et al. Differential regulation of formyl peptide and platelet-activating factor receptors. Role of phospholipase $\mathrm{C} \beta 3$ phosphorylation by protein kinase A. J Biol Chem. 1998;273(18):11012-11016.

45. Bai Y, Sanderson MJ. Airway smooth muscle relaxation results from a reduction in the frequency of $\mathrm{Ca} 2+$ oscillations induced by a cAMPmediated inhibition of the IP3 receptor. Respir Res. 2006;7:34.

46. Ay B, Iyanoye A, Sieck GC, Prakash YS, Pabelick CM. Cyclic nucleotide regulation of store-operated $\mathrm{Ca} 2+$ influx in airway smooth muscle. Am J Physiol Lung Cell Mol Physiol. 2006;290(2):L278-L283.

47. Flamand N, Surette ME, Picard S, Bourgoin S, Borgeat P. Cyclic AMP-mediated inhibition of 5-lipoxygenase translocation and leukotriene biosynthesis in human neutrophils. Mol Pharmacol. 2002;62(2):250-256.

48. Luo M, Jones SM, Flamand N, Aronoff DM, Peters-Golden M, Brock TG. Phosphorylation by protein kinase A inhibits nuclear import of 5-lipoxygenase. J Biol Chem. 2005;280(49):40609-40616. 
49. Iannnone MA, Wolberg G, Zimmerman TP. Chemotactic peptide induces cAMP elevation in human neutrophils by amplification of the adenylate cyclase response to endogenously produced adenosine. J Biol Chem. 1989;264(34):20177-20180.

50. Theron AJ, Steel HC, Tintinger GR, Anderson R. Endogenous adenosine regulates neutrophil pro-inflammatory activities by cyclic AMP-dependent accelerated clearance of cytosolic calcium. Inflamm Res. 2002;51(12):594-602.

51. Parry GCN, Mackman N. Role of cyclic AMP response element-binding protein in cyclic AMP inhibition of NF- $\mathrm{KB}$-mediated transcription. J Immunol. 1997;159(11):5450-5456.

52. Tacon CR, Newton R, Proud D, Leigh R. Rhinovirus-induced MMP-9 expression is dependent on Fra-1, which is modulated by formoterol and dexamethasone. J Immunol. 2012;188(9):4621-4630.

53. Cobelens PM, Kavelaars A, Vroon A, et al. The $\beta 2$-adrenergic agonist salbutamol potentiates oral induction of tolerance, suppressing adjuvant arthritis and antigen-specific immunity. J Immunol. 2002;169(9): 5028-5035.

54. Park PH, Huang H, McMullen MR, Bryan K, Nagy LE. Activation of cyclic-AMP response element binding protein contributes to adiponectin-stimulated interleukin-10 expression in RAW 264-267 macrophages. J Leukoc Biol. 2008;83(5):1258-1266.

55. Alvarez Y, Municio C, Alonso S, Sánchez Crespo M, Fernández N. The induction of IL-10 by zymosan in dendritic cells depends on CREB activation by the coactivators CREB-binding protein and TORC2 and autocrine PGE2. J Immunol. 2009;183(2):1471-1479.

56. Avni D, Ernst O, Philosoph A, Zor T. Role of CREB in modulation of TNF $\alpha$ and IL-10 expression in LPS-stimulated RAW264.7 macrophages. Mol Immunol. 2010;47(7-8):1396-1403.

57. Tamassia N, Zimmermann M, Castellucci M, et al. Cutting edge: An inactive chromatin configuration at the IL-10 locus in human neutrophils. J Immunol. 2013;190(5):1921-1925.

58. Giembycz MA, Kaur M, Leigh R, Newton R. A holy grail of asthma management: toward understanding how long-acting $\beta 2$-adrenoceptor agonists enhance the clinical efficacy of inhaled corticosteroids. $\mathrm{Br} J$ Pharmacol. 2008;153(6):1090-1104.

59. Ismaili N, Garabedian MJ. Modulation of glucocorticoid receptor function via phosphorylation. Ann NY Acad Sci. 2004;1024:86-101.

60. Kumar R, Calhoun WJ. Differential regulation of the transcriptional activity of the glucocorticoid receptor through site-specific phosphorylation. Biologics. 2008;2(4):845-854.

61. Haske T, Nakao M, Moudgil VK. Phosphorylation of immunopurified rat liver glucocorticoid receptor by the catalytic subunit of cAMP-dependent protein kinase. Mol Cell Biochem. 1994;132(2): 163-171.

62. Peñuelas I, Encío IJ, López-Moratalla N, Santiago E. cAMP activates transcription of the human glucocorticoid receptor gene promoter. J Steroid Biochem Mol Biol. 1998;67(2):89-94.

63. Eickelberg O, Roth M, Lörx R, et al. Ligand-independent activation of the glucocorticoid receptor by beta2-adrenergic receptor agonists in primary human lung fibroblasts and vascular smooth muscle cells. J Biol Chem. 1999;274(2):1005-1010.

64. Roth M, Johnson PR, Rüdiger JJ, et al. Interaction between glucocorticoids and $\beta 2$ agonists on bronchial airway smooth muscle cells through synchronised cellular signalling. Lancet. 2002;360(9342): 1293-1299.

65. Usmani OS, Ito K, Maneechotesuwan K, et al. Glucocorticoid receptor nuclear translocation in airway cells after inhaled combination therapy. Am J Respir Crit Care Med. 2005;172(6):704-712.

66. Kaur M, Chivers JE, Giembycz MA, Newton R. Long-acting $\beta 2$-adrenoceptor agonists synergistically enhance glucocorticoiddependent transcription in human airway epithelial and smooth muscle cells. Mol Pharmacol. 2008;73(1):203-214.

67. Anacker C, Zunszain PA, Cattaneo A, et al. Antidepressants increase human hippocampal neurogenesis by activating the glucocorticoid receptor. Mol Psych. 2011;16(7):738-750.
68. Pace TW, Hu F, Miller AH. Activation of cAMP-protein kinase A abrogates STAT5-mediated inhibition of glucocorticoid receptor signaling by interferon-alpha. Brain Behav Immun. 2011;25(8): 1716-1724.

69. Barnes PJ. Severe asthma: Advances in current management and future therapy. J Allergy Clin Immunol. 2012;129(1):48-59.

70. Perng DW, Su KC, Chou KT, et al. Long-acting $\beta 2$ agonists and corticosteroids restore the reduction of histone deacetylase activity and inhibit H2O2-induced mediator release from alveolar macrophages. Pulm Pharmacol Ther. 2012;25(4):312-318.

71. Rossios C, To Y, Osoata G, Ito M, Barnes PJ, Ito K. Corticosteroid insensitivity is reversed by formoterol via phosphoinositide-3-kinase inhibition. Br J Pharmacol. 2012;167(4):775-786.

72. Ohnishi H, Miyahara N, Gelfand EW. The role of Leukotriene B4 in allergic diseases. Allergol Int. 2008;57(4):291-298.

73. Black JL, Oliver BGG, Roth M. Molecular mechanisms of combination therapy with inhaled corticosteroids and long-acting $\beta$-agonists. Chest. 2009;136(4):1095-1100.

74. Mercado N, Hakim A, Kobayashi Y, et al. Restoration of corticosteroid sensitivity by p38 mitogen activated protein kinase inhibition in peripheral blood mononuclear cells from severe asthma. PLoS One. 2012;7(7):e41582.

75. Bos JL. Epac proteins: multi-purpose cAMP targets. Trends Biochem Sci. 2006;31(12):680-686.

76. Misra UK, Kaczowka S, Pizzo SV. The cAMP-activated GTP exchange factor, Epac1 upregulates plasma membrane and nuclear Akt kinase activities in 8-CPT-2-O-Me-cAMP-stimulated macrophages: Gene silencing of the cAMP-activated GTP exchange Epac1 prevents 8-CPT2-O-Me-cAMP activation of Akt activity in macrophages. Cell Signal. 2008;20(8):1459-1470.

77. Liu J, Zhao X, Cao J, et al. Differential roles of PKA and Epac on the production of cytokines in the endotoxin-stimulated primary cultured microglia. J Mol Neurosci. 2011;45(2):186-193.

78. Lovén J, Svitacheva N, Jerre A, Miller-Larsson A, Korn SH. Antiinflammatory activity of beta 2-agonists in primary lung epithelial cells is independent of glucocorticoid receptor. Eur Respir J. 2007;30(5): 848-856.

79. Donnelly LE, Tudhope SJ, Fenwick PS, Barnes PJ. Effects of formoterol and salmeterol on cytokine release from monocyte-derived macrophages. Eur Respir J. 2010;36(1):178-186.

80. Kobayashi Y, Mercado N, Miller-Larsson A, Barnes PJ, Ito K. Increased corticosteroid sensitivity by a long acting $\beta 2$ agonist formoterol via $\beta 2$ adrenoceptor independent protein phosphatase 2A activation. Pulm Pharmacol Ther. 2012;25(3):201-207.

81. Matthay MA, Thompson BT, Brower R. Inflammation-induced desensitization of $\beta$-receptors in acute lung injury. Am J Respir Crit Care Med. 2012;185(8):894-895.

82. Finney PA, Belvisi MG, Donnelly LE, et al. Albuterol-induced downregulation of Gsalpha accounts for pulmonary $\beta 2$-adrenoceptor desensitization in vivo. J Clin Invest. 2000;106(1):125-135.

83. Barnes PJ. Corticosteroid resistance in patients with asthma and chronic obstructive pulmonary disease. J Allergy Clin Immunol. 2013;131(3): 636-645.

84. Hu A, Nino G, Grunstein JS, Fatma S, Grunstein MM. Prolonged heterologous $\beta 2$ - adrenoceptor desensitization promotes proasthmatic airway smooth muscle function via PKA/ERK1/2-mediated phosphodiesterase-4 induction. Am J Physiol Lung Cell Mol Physiol. 2008; 294(6):L1055-L1067.

85. Su Y, Jackson EK, Gorelik E. Receptor desensitization and blockade of the suppressive effects of prostaglandin E2 and adenosine on the cytotoxic activity of human melanoma-infiltrating $\mathrm{T}$ lymphocytes. Cancer Immunol Immunother. 2011;60(1):111-122.

86. Fogli S, Stefanelli, Martelli A, et al. Protective effect of high-dose montelukast on salbutamol-induced homologous desensitisation in airway smooth muscle. Pulm Pharmacol Ther. 2013; pii: S10945539(13)00136-3. 
87. Pauwels RA, Löfdahl CG, Postma DS, et al. Effect of inhaled formoterol and budesonide on exacerbations of asthma. Formoterol and Corticosteroids Establishing Therapy (FACET) International Study Group. N Engl J Med. 1997;337(20):1405-1411.

88. Donohue JF. Combination therapy for chronic obstructive pulmonary disease: clinical aspects. Proc Am Thorac Soc. 2005;2(4): 272-281.

89. Loukides S, Bartziokas K, Vestbo J, Singh D. Novel Anti-inflammatory agents in COPD: Targeting lung and systemic inflammation. Curr Drug Targets. 2013;14(2):235-245.

90. Page CP, Spina D. Selective PDE inhibitors as novel treatments for respiratory diseases. Curr Opin Pharmacol. 2012;12(3):275-286.

91. Moodley T, Wilson S, Joshi T, et al. Phosphodiesterase 4 inhibitors augment the ability of formoterol to enhance glucocorticoid-dependent gene transcription in human airway epithelial cells: A novel mechanism for the clinical efficacy of roflumilast in severe COPD. Mol Pharmacol. 2013;83(4):894-906.

92. Anonymous. Roflumilast: doubtful efficacy but clear harms in COPD. Prescrire Int. 2013;22(134):5-9.

93. Tintinger GR, Feldman C, Theron AJ, Anderson R. Montelukast: More than a cysteinyl leukotriene receptor agonist? Sci World J. 2010;10: 2403-2413.

94. Anderson R, Theron AJ, Gravett CM, Steel HC, Tintinger GR, Feldman C. Montelukast inhibits neutrophil pro-inflammatory activity by a cyclic AMP-dependent mechanism. Br J Pharmacol. 2009; 156(1):105-115.

95. Keith PK, Koch C, Djandji M, et al. Montelukast as add-on therapy with inhaled corticosteroids alone or inhaled corticosteroids and long-acting beta-2-agonists in the management of patients diagnosed with asthma and concurrent allergic rhinitis (the RADAR trial). Can Respir J. 2009;16 Suppl A:17A-31A.

96. Korn D, Van den Brande P, Potvin E, Dramaix M, Herbots E, Peché R. Efficacy of add-on montelukast in patients with non-controlled asthma: a Belgian open-label study. Curr Med Res Opin. 2009;25(2): 489-497.

97. Bjerg A, Lundbäck B, Lötvall J. The future of combining inhaled drugs for COPD. Curr Opin Pharmacol. 2012;12(3):252-255.

98. Calverley PM, Boonsawat W, Cseke Z, Zhong N, Peterson S, Olsson H. Maintenance therapy with budesonide and formoterol in chronic obstructive pulmonary disease. Eur Respir J. 2003;22(6): 912-919.

99. Kornmann O, Dahl R, Centanni S, et al. Once-daily indacaterol versus twice-daily salmeterol for COPD: a placebo-controlled comparison. Eur Respir J. 2011;37(2):273-279.

100. Szafranski W, Cukier A, Ramirez A, et al. Efficacy and safety of budesonide/formoterol in the management of chronic obstructive pulmonary disease. Eur Respir J. 2003;21(1):74-81.

101. Campbell M, Eliraz A, Johansson G, et al. Formoterol for maintenance and as-needed treatment of chronic obstructive pulmonary disease. Respir Med. 2005;99(12):1511-1520.

102. Tashkin DP, Rennard SI, Martin P, et al. Efficacy and safety of budesonide and formoterol in one pressurized metered-dose inhaler in patients with moderate to very severe chronic obstructive pulmonary disease: results of a 6-month randomized clinical trial. Drugs. 2008; 68(14):1975-2000.

103. Tashkin DP, Doherty DE, Kerwin E, et al. Efficacy and safety of a fixeddose combination of mometasone furoate and formoterol fumarate in subjects with moderate to very severe COPD: results from a 52-week Phase III trial. Int J Chron Obstruct Pulmon Dis. 2012;7: 43-55.

104. Mahler DA, Wire P, Horstman D, et al. Effectiveness of fluticasone propionate and salmeterol combination delivered via the Diskus device in the treatment of chronic obstructive pulmonary disease. Am J Respir Crit Care Med. 2002;166(8):1084-1091.

105. Chapman KR, Arvidsson P, Chuchalin AG, et al. The addition of salmeterol 50 microg bid to anticholinergic treatment in patients with COPD: a randomized, placebo controlled trial. Chronic obstructive pulmonary disease. Can Respir J. 2002;9(3):178-185.
106. Calverley P, Pauwels R, Vestbo J, et al. Combined salmeterol and fluticasone in the treatment of chronic obstructive pulmonary disease: a randomised controlled trial. Lancet. 2003;361(9356):449-456.

107. Brusasco V, Hodder R, Miravitlles M, Korducki L, Towse L, Kesten S. Health outcomes following treatment for six months with once daily tiotropium compared with twice daily salmeterol in patients with COPD. Thorax. 2003;58(5):399-404.

108. Hanania NA, Darken P, Horstman D, et al. The efficacy and safety of fluticasone propionate ( $250 \mathrm{microg}) / \mathrm{salmeterol}$ ( 50 microg) combined in the Diskus inhaler for the treatment of COPD. Chest. 2003;124(3): 834-843.

109. Stockley RA, Chopra N, Rice L. Addition of salmeterol to existing treatment in patients with COPD: a 12 month study. Thorax. 2006; 61(2):122-128.

110. Donohue JF, van Noord JA, Bateman ED, et al. A 6-month, placebocontrolled study comparing lung function and health status changes in COPD patients treated with tiotropium or salmeterol. Chest. 2002;122(1):47-55.

111. Decramer ML, Hanania NA, Lötvall JO, Yawn BP. The safety of long-acting beta2-agonists in the treatment of stable chronic obstructive pulmonary disease. Int J Chron Obstruct Pulmon Dis. 2013;8: 53-64.

112. Vogelmeier C, Hederer B, Glaab T et al. Tiotropium versus salmeterol for the prevention of exacerbations of COPD. $N$ Engl J Med. 2011;364(12):1093-1103.

113. Wedzicha JA, Calverley PM, Seemungal TA, et al. The prevention of chronic obstructive pulmonary disease exacerbations by salmeterol/ fluticasone propionate or tiotropium bromide. Am J Respir Crit Care Med. 2008;177(1):19-26.

114. Larsson K, Janson C, Lisspers K, et al. Combination of budesonide/ formoterol more effective than fluticasone/salmeterol in preventing exacerbations in chronic obstructive pulmonary disease: the PATHOS study. J Intern Med. 2013;273(6):584-594.

115. Niewoehner DE, Rice K, Cote C, et al. Prevention of exacerbations of chronic obstructive pulmonary disease with tiotropium, a once-daily inhaled anticholinergic bronchodilator: a randomized trial. Ann Intern Med. 2005;143(5):317-326.

116. Dusser D, Bravo ML, Iacono P. The effect of tiotropium on exacerbations and airflow in patients with COPD. Eur Respir J. 2006;27(3) 547-555.

117. Powrie DJ, Wilkinson TM, Donaldson GC, et al. Effect of tiotropium on sputum and serum inflammatory markers and exacerbations in COPD. Eur Respir J. 2007;30(3):472-478.

118. Chan CK, Maltais F, Sigouin C, Haddon JM, Ford GT; SAFE Study Group. A randomized controlled trial to assess the efficacy of tiotropium in Canadian patients with chronic obstructive pulmonary disease. Can Respir J. 2007;14(8):465-472.

119. Casaburi R, Mahler DA, Jones PW, et al. A long-term evaluation of once-daily inhaled tiotropium in chronic obstructive pulmonary disease. Eur Respir J. 2002;19(2):217-224.

120. Cazzola M, Tashkin DP. Combination of formoterol and tiotropium in the treatment of COPD: effects on lung function. COPD. 2009;6(5):405-415.

121. van Noord JA, Aumann JL, Janssens E, et al. Comparison of tiotropium once daily, formoterol twice daily and both combined once daily in patients with COPD. Eur Respir J. 2005;26(2):214-222.

122. van Noord JA, Aumann JL, Janssens E, et al. Effects of tiotropium with and without formoterol on airflow obstruction and resting hyperinflation in patients with COPD. Chest. 2006;129(3): 509-517.

123. Tashkin DP, Pearle J, Iazzoni D, Varghese ST. Formoterol and tiotropium compared with tiotropium alone for COPD. COPD. 2009;6(1): $17-25$.

124. Tashkin DP, Littner M, Andrews CP, Tomlinson L, Rinehart M, Denis-Mize K. Concomitant treatment with nebulized formoterol and tiotropium in subjects with COPD: a placebo-controlled trial. Respir Med. 2008;102(4):479-487. 
125. Cazzola M, Di Marco F, Santus P, et al. The pharmacodynamic effects of single inhaled doses of formoterol, tiotropium and their combination in patients with COPD. Pulm Pharmacol Ther. 2004;17(1): 35-39.

126. Aaron S, Vandemheen KL, Fergusson D, et al. Tiotropium in combination with placebo, salmeterol, or fluticasone-salmeterol for treatment of chronic obstructive pulmonary disease: a randomized trial. Ann Intern Med. 2007;146(8):545-555.

127. Cazzola M, Molimard M. The scientific rationale for combining longacting beta2-agonists and muscarinic antagonists in COPD. Pulm Pharmacol Ther. 2010;23(4):257-267.

128. Short PM, Williamson PA, Elder DHJ, Lipworth SI, Schembri S, LipworthBJ. The impact of tiotropium on mortality and exacerbations when added to inhaled corticosteroids and long-acting $\beta$-agonist therapy in COPD. Chest. 2012;141(1):81-86.

129. Rossi A, Polese G. Indacaterol: a comprehensive review. Int J Chron Obstruct Pulmon Dis. 2013;8:353-363.

130. Wollin L, Pieper MP. Tiotropium bromide exerts ant-inflammatory activity in a cigarette smoke mouse model of COPD. Pulm Pharmacol Ther. 2010;23(4):345-354.

131. Karner C, Cates CJ. The effect of adding inhaled corticosteroids to tiotropium and long-acting beta2-agonists for chronic obstructive pulmonary disease. Cochrane Database Syst Rev. 2011;9:CD009039.
132. Karner C, Cates CJ. Long-acting beta2-agonists in addition to tiotropium versus either tiotropium or long-acting beta2-agonist alone for chronic obstructive pulmonary disease. Cochrane Database Syst Rev. 2012;4:CD008989.

133. Mahler DA, D’Urzo A, Bateman ED, et al. Concurrent use of indacaterol plus tiotropium in patients with COPD provides superior bronchodilation compared with tiotropium alone: a randomised, double-blind comparison. Thorax. 2012;67(9):781-788.

134. Profita M, Bonanno A, Montalbano AM, et al. $\beta 2$ long-acting and anticholinergic drugs control TGF- $\beta 1$-mediated neutrophilic inflammation in COPD. Biochim Biophys Acta. 2012;1822(7):1079-1089.

135. Kerstjens HA, Disse B, Schröder-Babo W, et al. Tiotropium improves lung function in patients with severe uncontrolled asthma: a randomized controlled trial. J Allergy Clin Immunol. 2011;128(2): 308-314.

136. Bateman ED, Kornmann O, Ambery C, et al. Pharmacodynamics of GSK961081, a bi-functional molecule, in patients with COPD. Pulm Pharmacol Ther. 2013;26(5):581-587.

137. Sears MR. The FDA-mandated trial of safety of long-acting beta-agonists in asthma: finality or frutility? Thorax. 2013;68(2):195-198.
Drug Design, Development and Therapy

\section{Publish your work in this journal}

Drug Design, Development and Therapy is an international, peerreviewed open-access journal that spans the spectrum of drug design and development through to clinical applications. Clinical outcomes, patient safety, and programs for the development and effective, safe, and sustained use of medicines are a feature of the journal, which

\section{Dovepress}

has also been accepted for indexing on PubMed Central. The manuscript management system is completely online and includes a very quick and fair peer-review system, which is all easy to use. Visit http://www.dovepress.com/testimonials.php to read real quotes from published authors.

Submit your manuscript here: http://www.dovepress.com/drug-design-development-and-therapy-journal 